\title{
PENGARUH MODEL PROBLEM BASED LEARNING BERBANTU PETA PIKIRAN (MIND MAP) TERHADAP HASIL BELAJAR SISWA
}

\author{
Afyka Sari Sinulingga dan Rita Juliani \\ Jurusan Fisika FMIPA Universitas Negeri Medan \\ Afykasari244@gmail.com
}

\begin{abstract}
ABSTRAK
Penelitian dilakukan bertujuan untuk mengetahui pengaruh model problem based learning berbantu teknik peta pikiran (mind map) terhadap hasil belajar siswa pada materi Fluida Dinamis di kelas XI semester II SMA Negeri 1 Sunggal T.P 2015/2016. Jenis penelitian adalah quasi experiment. Populasi penelitian adalah seluruh siswa kelas XI yang berjumlah enam kelas. Sampel dipilih dengan teknik cluster random sampling kelas XI MIA-1 sebagai kelas kontrol dan MIA-2 sebagai kelas eksperimen dengan masing-masing kelas berjumlah 31 orang. Instrumen yang digunakan berupa soal essay tes sebanyak 10 soal yang telah divalidasi untuk mengukur hasil belajar. Hasil penelitian menunjukkan rata-rata nilai pretes kelas eksperimen 40,48 dan kelas kontrol 42,58. Pengujian normalitas dan homogenitas kedua kelas diperoleh data berdistribusi normal dan homogen. Kemudian diberi perlakuan yaitu kelas eksperimen dengan model problem based learning berbantu teknik peta pikiran (mind map) dan kelas kontrol dengan pembelajaran konvensional serta diberikan postes dengan hasil nilai rata-rata kelas eksperimen 75,16 dan kelas kontrol 66,13. Pengujian normalitas dan homogenitas diperoleh data postes berdistribusi normal dan varians homogen. Hasil uji beda $t_{\text {hitung }}>t_{\text {tabel }}$ maka $H_{a}$ diterima yang berarti ada pengaruh yang signifikan penerapan model problem based learning berbantu teknik peta pikiran (mind map) pada materi Fluida Dinamis di kelas XI semester II SMA Negeri 1 Sunggal T.P 2015/2016.
\end{abstract}

Kata kunci : problem based learning, mind map, hasil belajar

\section{ABSTRACT}

This studies have been conducted to determine the effect models of problem based learning assistend technique mind maps (mind mapping) on the material fluid dynamic in the second half of class XI SMA Negeri 1 Sunggal T.P 2015/2016. This type of research is quasi-experimental. The study population was all studies of class XI of six classes. The sample was selected by random cluster sampling technique class XI MIA-1 as the control class and MIA-2 as the experimental class with each class numbered 31 people. Instruments used in the form of essay test as many as 10 questions that have been validated to measure learning outcomes. The results showed an average value of 40,48 pretest experimental class and control 42,58. Testing normality and homogen of both classes of normal distributed of data obtained and homogenized. Then given a treatment that is experimental class with a problen based learning models using 
the technique of mind mapping and grade control with conventional learning and given postes with the results of the average value of 75,16 experimental class and control class 66,13. Testing normality and homogeneity posstest data showed normality distribution and variance homogeneity. Different test $t_{\text {count }}>t_{\text {table }}$ then $H_{a}$ accepted which means there is significant influence application of the modelassistend engineering problem based learning using mind mapping on a dynamic fluid material in second class XI half of the domestic SMA 1 Sunggal T.P 2015/2016.

Keywords: Problem Based Learning, mind mapping, learning outcomes

\section{PENDAHULUAN}

Perkembangan pendidikan di Indonesia dari tahun ke tahun mengalami perubahan seiring dengan tantangan dalam menyiapkan sumber daya manusia yang berkualitas dan mampu bersaing di era global. Salah satu permasalahan yang di hadapi oleh bangsa adalah masih rendahnya kualitas pendidikan pada setiap jenjang karena lemahnya proses pembelajaran (Trianto, 2011).

Pendidikan adalah salah satu bentuk perwujudan kebudayaan manusia yang dinamis dan sarat perkembangan. Perubahan atau perkembangan pendidikan terjadi sejalan dengan perubahan budaya kehidupan. Perbaikan pendidikan disemua tingkat perlu dilakukan antipasi sebagai kepentingan masa depan. Pelaksanaan pendidikan tidak terlepas dari proses pembelajaran di sekolah.

Deli Serdang adalah salah satu kabupaten di Sumatera Utara, perkembangan pendidikan di kabupaten Deli Serdang sudah baik serta didukung dengan tingkat kelulusan Ujian Nasional (UN) untuk tingkat SMA mencapai $100 \%$ dengan jumlah 11.621 siswa yang mengikuti ujian nasional (Rhamadani, 2015).
Hasil observasi penelitian pada tanggal 19 Desember 2015, siswa SMA Negeri 1 Sunggal berpendapat bahwa pelajaran Fisika sulit dipahami, kurang menarik dan banyak siswa yang kurang minat dengan pelajaran fisika. Pengalaman peneliti didukung dalam melaksanakan Program Pengalaman Lapangan Terpadu (PPLT) tahun 2015, hal yang sama dialami oleh sebuah sekolah SMA Swasta Karya Bakti. Siswa mengatakan bahwa pelajaran fisika sulit dan banyak rumus dalam perhitunganperhitungan yang tidak mampu ia kuasai. Ada anggapan bahwa pelajaran fisika hanya perlu bagi yang pintar dan yang menyukainya saja, akibatnya fisika terasa asing dalam kehidupan siswa sehingga pelajaran fisika dianggap sulit dan membosankan. Anggapan siswa berkaitan dengan masalah kualitas rancangan pengajaran fisika yang disajikan guru dalam kegiatan pembelajaran karena guru lebih dominan menyajikan materi fisika dengan menonjolkan persamaanpersamaan matematik dalam bentuk yang kurang menarik dan terkesan sulit bagi siswa. Rendahnya hasil belajar fisika yang diperoleh siswa juga disebabkan karena faktor yang berhubungan dengan suasana belajar 
dikelas, keterbatasan sarana prasarana dan alat peraga menjadi kendala dalam pembelajaran di kelas.

Hasil wawancara peneliti dengan guru mata pelajaran Fisika SMA Negeri 1 Sunggal, Ibu Hayati berpendapat bahwa intraksi siswa dengan mata pelajaran fisika masih kurang menarik minat siswa sehingga hasil belajar yang mereka peroleh masih standart Kriteria Ketuntasan Minimal (KKM) 75 dan dominan di bawah KKM mata pelajaran, akan tetapi sebagian siswa merespon cukup baik dan mau bertanya dengan materi fisika yang diajarkan di kelas.

Rendahnya hasil belajar siswa berdasarkan wawancara guru dan angket siswa pada mata pelajaran fisika yaitu: (1) Siswa masih belum menyadari manfaat fisika dalam kehidupannya; (2) Banyak siswa yang beranggapan bahwa fisika merupakan mata pelajaran hitungan; (3) Siswa beranggapan fisika terlalu rumit dan hanya orang yang pintar saja yang dapat memahami fisika.

Menyikapi masalah, perlu adanya upaya yang dilakukan oleh guru untuk menggunakan teknik pembelajaran yang membuat siswa lebih tertarik dalam belajar yaitu menggunakan model Problem Based Learning berbantu teknik Mind Map.

Problem based learning
merupakan pembelajaran yang
penyampaianya dilakukan dengan
cara menyajikan suatu permasalahan,
mengajukan pertanyaan-pertanyaan,
memfasilitasi penyelidikan, dan
membuka dialog. Permasalahan

yang dikaji hendaknya merupakan permasalahan kontekstual yang ditemukan oleh peserta didik dalam kehidupan sehari-hari. Permasalahan harus dipecahkan dengan menerapkan beberapa konsep dan prinsip yang secara simultan dipelajari dan tercakup dalam kurikulum mata pelajaran (Sani, 2014).

Svantesson

(2004), mengatakan bahwa "peta pikiran mampu membantu mengembangkan kreativitas juga kemampuan analitis dan logika". Mind map merupakan teknik mencatat yang mengembangkan gaya belajar visual yang memadukan dan mengembangkan potensi kerja otak yang terdapat di dalam diri seseorang. Penggunaan Mind map menyebabkan guru lebih menikmati proses pembelajaran dan berfikir bahwa dapat memotivasi siswa dalam pelajaran sains. Mind mapping digunakan untuk menyampaikan pesan atau informasi materi pelajaran kepada siswa agar siswa lebih tertarik terhadap materi pelajaran dan bersemangat dalam proses pembelajaran (Maisyarah, 2013).

Imaduddin dan Utomo (2012), menyatakan hasil analisis data dengan menggunakan teknik uji$\mathrm{t}$ yaitu paired samplet-test telah membuktikan bahwa prestasi belajar fisika pada kelompok yang diberikan perlakuan berupa penggunaan mind mapping dalam proses kegiatan belajar mengajar (KBM) dalam kelompok eksperimen lebih tinggi dibandingkan dengan kelompok yang menggunakan metode konvensional. 


\begin{abstract}
Berdasarkan permasalahan penting dilakukan penelitian pengaruh model problem based learning berbantu peta pikiran (Mind Map) terhadap hasil belajar siswa di kelas XI SMA Negeri 1 Sunggal dengan materi Fluida Dinamis.
\end{abstract}

\section{METODE PENELITIAN}

Penelitian dilaksanakan di SMA Negeri 1 Sunggal yang beralamat J1. Mencirim Sei Semayang, km 14 Kecamatan Sunggal, kabupaten Deli Serdang. Populasi dalam penelitian adalah seluruh siswa kelas XI semester II SMA Negeri 1 Sunggal T.P. 2015/2016 berjumlah 210 orang yang terdiri dari 6 kelas.

Sampel diambil 2 kelas dengan cara cluster random sampling, Kelas eksperimen yaitu kelas yang diajar dengan model problem based learning berbantu peta pikiran (mind map) pada kelas XI MIA-2 dan kelas kontrol yaitu kelas yang diajar menggunakan model pembelajaran konvensional pada kelas MIA-1, masing-masing kelas berjumlah 31 siswa.

Penelitian termasuk jenis penelitian quasi experiment yaitu merupakan penelitian yang dimaksudkan untuk mengetahui ada tidaknya pengaruh dari sesuatu yang dikenakan yaitu model problem Based Learning berbantu teknik peta pikiran (Mind Map) dari guru pada subjek yaitu siswa. Instrumen penelitian diberikan tes sebanyak dua kali yaitu sebelum perlakuan (pretest) dan sesudah perlakuan (posttest).

Teknik analisis data terdiri dari uji prasyarat dan uji hipotesis.
Uji normalitas digunakan untuk mengetahui apakah data kedua sampel berdistribusi normal atau tidak dengan menggunakan uji Lilliefors, Sedangkan untuk menguji homogenitas digunakan uji $\mathrm{F}$ dan pengujian hipotesis yang digunakan adalah Uji-t, dengan rumus:

$$
=\frac{t^{X_{1}}-\overline{X_{2}}}{s \sqrt{\frac{1}{n_{1}}+\frac{1}{n_{2}}}}
$$

Tetapi jika kedua kelas tidak homogen, maka menggunakan :

$$
t=\frac{\overline{X_{1}}-\overline{X_{2}}}{S \sqrt{\frac{S_{1}{ }^{2}}{n_{1}}-\frac{S_{2}{ }^{2}}{n_{2}}}}
$$

Dan jika kedua simpangan baku tidak sama tetapi kedua populasi berdistribusi normal, maka menggunakan:

$$
t^{\prime}=\frac{\overline{X_{1}}-\overline{X_{2}}}{S \sqrt{\frac{n_{1}}{S_{1}{ }^{2}}-\frac{n_{2}}{S_{2}{ }^{2}}}}
$$

dengan kriteria pengujian terima $H_{o}$ jika $t_{\text {hitung }}<t_{\text {tabel }}$ dimana $t_{1-\alpha}$ didapat dari distribusi $\mathrm{t}$ dengan $d k=n_{1}+n_{2}-2$ dan peluang (1- $\left.\alpha\right)$. Harga - harga $t$ lainnya $H_{o}$ ditolak, bila analisis data menunjukkan bahwa $t<t_{1-\alpha}$, maka hipotesis $\mathrm{H}_{\mathrm{o}}$ diterima, berarti keterampilan proses sains siswa pada kelas eksperimen (dengan model problem based learning berbantu teknik (mind map) sama dengan pembelajaran konvensional siswa pada kelas kontrol. Analisis data menunjukkan harga $t$ yang lain, maka $\mathrm{H}_{\mathrm{o}}$ ditolak 
dan terima $\mathrm{H}_{\mathrm{a}}$, berarti ada pengaruh model problem based learning berbantu peta pikiran (mind map) pada kelas eksperimen terhadap hasil belajar siswa.lebih baik dibandingkan model konvensional pada kelas kontrol.

\section{HASIL PENELITIAN \\ PEMBAHASAN}

DAN

\section{Hasil Penelitian}

Penelitian melibatkan dua kelas yang diberikan perlakuan yang berbeda, yaitu model problem based learning berbantu peta pikiran (mind map) untuk kelas eksperimen dan pembelajaran konvensional untuk kelas kontrol. Tahap awal penelitian kedua kelas terlebih dahulu diberikan pretes yang bertujuan untuk mengetahui kemam-puan awal siswa pada masing-masing kelas, kemudian diberikan perlakuan selama tiga kali pertemuan pada kelas eksperimen, dan masing-masing kelas diberikan postes untuk melihat pengaruh model yang diberikan.

Data hasil penelitian menunjukkan rata-rata nilai pretes kelas eksperimen 40,48. Distribusi nilai dan frekuensi dinyatakan pada gambar 1.
Nilai Pretes Kelas Eksperimen

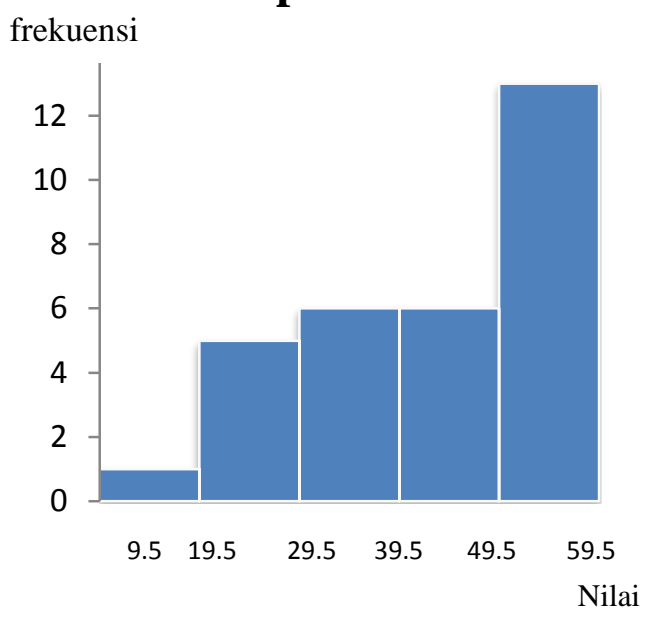

Gambar 1 Diagram data pretes kelas eksperimen

Nilai kelas kontrol untuk pretes diperoleh 42,58. Distribusi nilai dan frekuensi dinyatakan pada Gambar 2.

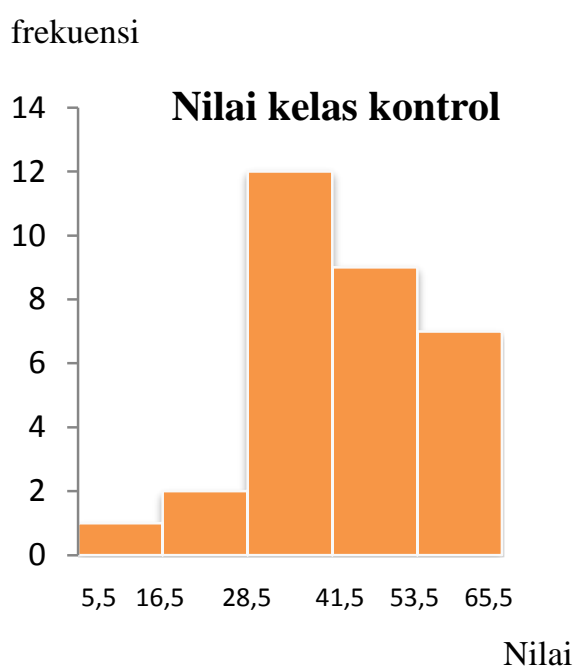

Gambar 2 Diagram batang data pretes kelas kontrol

Pengujian normalitas dan homogenitas, kedua kelas diperoleh bahwa data kedua kelas berdistribusi normal dan homogen. Hasil uji beda nilai kedua kelas untuk pretes 
diperoleh $t_{\text {hitung }}=0,71$ dan $t_{\text {tabel }}=2,0$ karena $t_{\text {hitung }}<t_{\text {tabel }}$, maka dapat dinyatakan bahwa kemampuan awal siswa kedua kelas sampel sama, kemudian diberi perlakuan yaitu kelas eksperimen dengan model problem based learning berbantu teknik peta pikiran (mind map) dan kelas kontrol dengan pembelajaran konvensional. Pembelajaran selesai maka diberikan postes dengan hasil nilai rata-rata kelas eksperimen 75,16 dan kelas kontrol 66,13. Pada pengujian normalitas dan homogenitas diperoleh bahwa data postes berdistribusi normal dan variansnya homogen. Hasil uji beda nilai kedua kelas diperoleh thitung= 3,20 dan $t_{\text {tabel }}=1,67$ untuk $\alpha=0,05$ dan $\mathrm{dk}=60$. Karenat hitung $>\mathrm{t}_{\text {tabel }}$ maka $\mathrm{H}_{\mathrm{a}}$ diterima yang berarti bahwa ada pengaruh yang signifikan penerapan model pembelajaran problem based learning dengan menggunakan teknik peta pikiran (mind map) pada materi pokok Fluida Dinamis di kelas XI semester II SMA Negeri 1 Sunggal T.P 2015/2016.

Hasil uji normalitas data dengan menggunakan uji Liliefors diperoleh bahwa $\mathrm{L}_{\text {hitung }}<\mathrm{L}_{\text {tabel }}$ maka dapat disimpulkan bahwa data pretes dan postes kedua kelompok sampel berdistribusi normal. Nilai kelas kontrol 42,58 maka distribusi nilai dan frekuensi postes kelas kontrol dinyatakan pada Gambar 3.

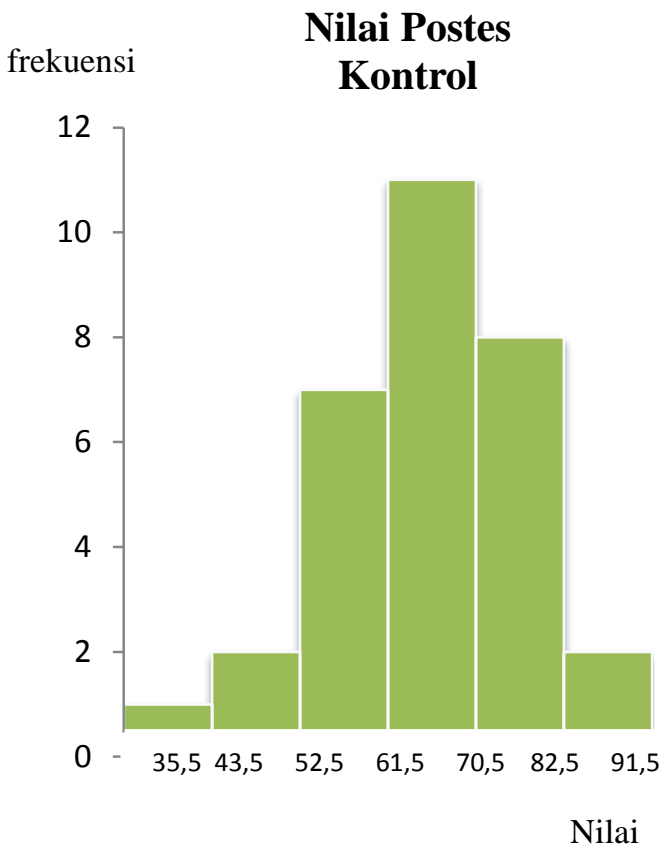

Gambar 3 Diagram data postes kelas kontrol.

Hasil penelitian menunjukkan bahwa ada pengaruh model Problem Based Learning berbantu teknik peta pikiran (Mind Map) terhadap hasil belajar siswa pada materi fluida dinamis di Kelas XI Semester II di SMA Negeri 1 Sunggal T.P 2015/2016. Hasil belajar antara kelas eksperimen dengan kelas kontrol diperoleh nilai pretes kelas eksperimen 40,48 dan kelas kontrol 42,58 sedangkan hasil postes dengan nilai rata-rata kelas eksperimen 75,16 . Distribusi nilai dan frekuensi kelas dinyatakan pada gambar 4 . 


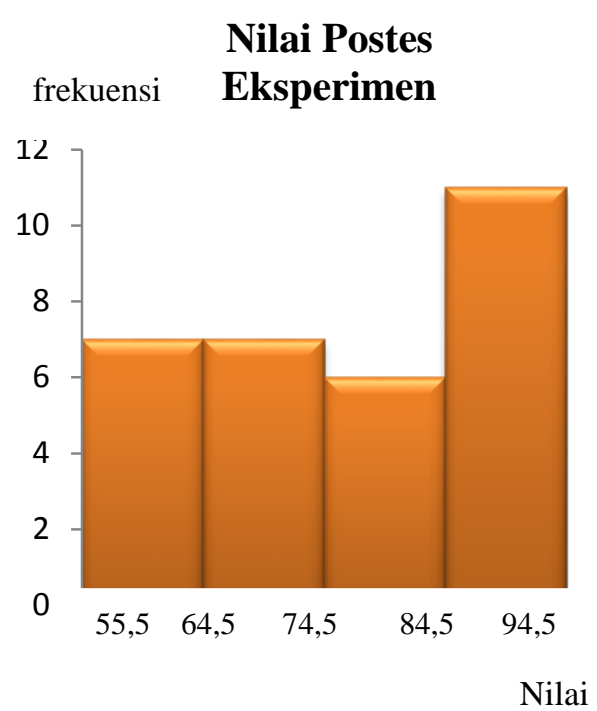

Gambar 4 Diagram data postes kelas ekperimen

Hasil uji hipotesis $t_{\text {hitung }}=3,20$ dan $t_{\text {tabel }}=1,67$ untuk $\alpha=0,05 \mathrm{dan} \mathrm{dk}$ $=60$, maka $\mathrm{H}_{\mathrm{o}}$ ditolak dan $\mathrm{h}_{\mathrm{a}}$ diterima berarti model problem based learning berbantu peta pikiran (mind map) memiliki pengaruh yang lebih baik dari pada pembelajaran konvensional dalam materi fluida dinamis.

Model problem based learning berbantu peta pikiran (mind map) terdapat perbedaan hasil belajar dibandingkan dengan pembelajaran konvensional dikarenakan model problem based learning berbantu peta pikran (mind map) membawa siswa secara langsung kedalam proses ilmiah melalui ekperimen dengan tujuan membantu siswa mengembangkan intelektual yang diperlukan untuk mengajukan pertanyaan dan menemukan jawaban eksperimen dan nyata. Setiap pertemuan terlihat mempunyai perubahan melalui lembar kerja siswa yaitu perhitungan nilai LKS maka dapat dilihat bahwa terdapat peningkatan nilai rata-rata yang diperoleh mulai dari pertemuan I hinga pertemuan ke III.

Berdasarkan data perhitungan nilai LKS maka dapat dilihat bahwa terdapat penngkatan nilai rata-rata yang diperoleh mulai dari pertemuan I sampai pertemuan III dinyatatakan pada Gambar 5.

\section{Nilai LKS}

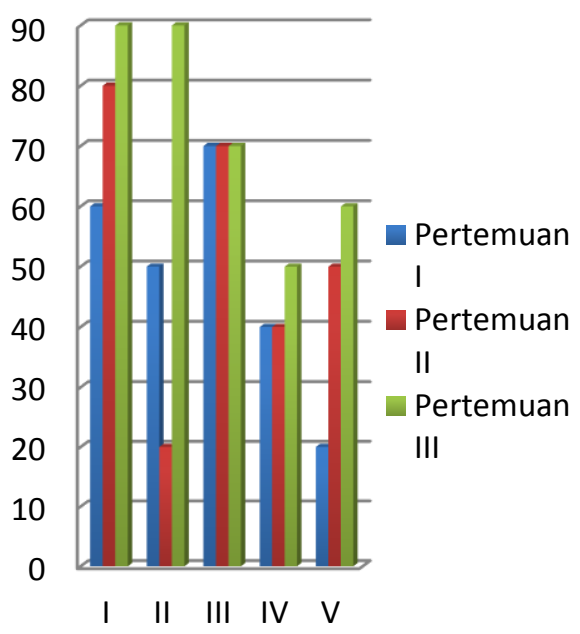

Gambar 5 Nilai LKS

\section{Pembahasan}

Penelitian merupakan quasi eksperimen yang dilakukan di SMA Negeri 1 Sunggal menggunakan sampel dua kelas yaitu XI MIA-2 yang diajar dengan menggunakan model pembelajaran problem based learning berbantu peta pikiran (mind map) pada kelas eksperimen dan kelas MIA-2 yang diajar dengan 
menggunakan model pembelajaran konvensional pada kelas kontrol. Penerapan model problem based learning berbantun teknik peta pikiran (mind map) didasarkan pada tujuan untuk meningkatkan penguasaan pengetahuan prosedural pada materi Fluida Dinamis.

Dilakukan tes awal (pretes) kepada masing-masing kelas terlebih dahulu sebelum diberikan pembelajaran yang berbeda dengan jumlah soal 10 butir dalam bentuk essay tes pada kedua kelas sampel untuk mengetahui kemampuan awal siswa pada materi Fluida Dinamis sebelum diberikan perlakuan pembelajaran. dimana pada kelas kontrol diajar oleh guru mata pelajaran dengan pembelajaran konvensional dan kelas eksperimen diajar oleh peneliti. Hasil rata-rata nilai pretes siswa kelas yang terpilih sebagai kelas eksperimen adalah sebesar 40,48 dengan simpangan baku 12,06. Sedangkan untuk kelompok siswa yang terpilih sebagai kelas kontrol diperoleh rata-rata pretes sebesar 42,58 dengan simpangan baku 11,39.

Hasil nilai rata-rata kedua kelas tergolong rendah karena hasil uji rata-rata pretes diperoleh $t_{\text {hitung }}=$ 0,71 dan $t_{\text {tabel }}=2,0$ untuk $\alpha=0,05$ dan $\mathrm{dk}=60$ dengan $\mathrm{t}_{\text {hitung }}<\mathrm{t}_{\text {tabel }}$ menunjukkan bahwa tidak ada perbedaan yang signifikan (nyata) kemampuan awal kedua kelompok siswa. Kemampuan awal siswa dilakukan pembelajaran yang berbeda, dikelas eksperimen diberi perlakuan dengan model Problem Based Learning berbantu teknik peta pikiran (Mind Map) dan dikelas kontrol di ajar dengar model pembelajaran konvensional (inquiry), dimana pada kelas kontrol diajar oleh guru mata pelajaran dan kelas eksperimen diajar oleh peneliti. Awal pembelajaran peneliti memberi pertanyaan dan pengetahuan awal sebelum pembelajaran berlangsung maka diberi sebuah masalah yang harus dipecahkan siswa diiringi dengan lembar kerja siswa (LKS). LKS dapat terjawab melalui sebuah praktikum/investigasi kelompok dalam menyelesaikan masalah yang dilakukan siswa dan menyimpulkan pembelajaran dimana dalam setiap pertemuan I, II, dan III memiliki peningkatan hasil belajar.

Akhir pembelajaran siswa diberikan postes untuk mengetahui bagaimana hasil belajar kedua kelompok. Nilai rata-rata postes kelas eksperimen yaitu 75,16 dengan simpangan baku 10,99 sedangkan nilai rata-rata postes kelas kontrol yaitu 66,13 dengan simpangan baku 11,52. Hasil uji-t diperoleh perbedaan rata-rata nilai postes yang signifikan dengan $t_{\text {hitung }}=3,20$ dan $\mathrm{t}_{\text {tabel }}=1,67$ untuk $\alpha=0,05 \mathrm{dan} \mathrm{dk}=$ 60 karena $t_{\text {hitung }}>t_{\text {tabel }}$, sehingga dapat disimpulkan bahwa ada pengaruh model Problem Based Learning 
berbantu teknik Mind Map terhadap hasil belajar siswa.

Model pembelajaran problem based learning mengadopsi teknik peta pikiran (mind map), yang dimana di ketahui bahwa teknik peta pikiran tidak memiliki sintaks pembelajaran, sehingga pada penelitian ini sintaks yang digunakan adalah model pembelajaran problem based learning. Model problem based learning berbantu teknik peta pikiran (mind map) dapat meningkatkan kemampuan berpikir kritis untuk mencari, memecahkan sebuah masalah dan dapat meningkatkan kreatifitas siswa. Prinsip pelaksanaan teknik pembelajaran peta pikiran (mind map) yaitu bagaimana membuat catatan dengan kata kunci teks pada materi dan melengkapinya dengan gambar dan simbol-simbol. Teknik peta pikiran (mind map) juga melibatkan kesenangan, kreativitas seorang siswa dalam membuat catatan sehingga siswa dapat belajar dengan senang dan lebih mudah untuk memahami dan mengingatnya. Adapun kelebihan dari teknik pembelajaran peta pikiran (mind map) dapat membantu kita dalam banyak hal. Berikut beberapa di antaranya: merencanakan, kreatif, komunikasi, menghemat waktu, menyelesaikan masalah, menyusun menjelaskan pikiran-pikiran, memusatkan perhatian, dan mengingat dengan lebih baik, belajar lebih cepat dan efisien, serta melihat gambar keseluruhan.

Prinsip model pembelajaran problem based learning memotivasi peserta didik untuk terlibat dalam kegiatan penyelesaian masalah sehingga mereka akan bertindak aktif membangun pengetahuanya, dalam penyelesaian masalah memerlukan analisis permasalahan dan identifikasi pengetahuan yang telah dimiliki, serta pengetahuan yang belum dikuasai. Sehingga penggabungan antara model problem based learning berbantu teknik peta pikiran (mind map) adalah pilihan yang tepat untuk meningkatkan kemampuan berpikir kritis siswa dan kreatif.

Tujuan utama penelitian ini adalah untuk mengetahui pengaruh model problem based learning berbantu teknik peta pikiran (mind map) terhadap hasil belajar siswa. Hasil belajar kelas eksperimen di peroleh dengan nilai rata-rata yang lebih tinggi di bandingkan dengan kelas kontrol. Nilai rata-rata kelas eksperimen telah mencapai standar kentutasan kelas, sedangkan kelas kontrol belum mencapai ketuntasan. Persentase peningkatan hasil belajar kelas eksperimen mencapai $57 \%$ dan kelas kontrol mencapai $41 \%$.

\section{KESIMPULAN DAN SARAN} Kesimpulan

Berdasarkan data hasil penelitian yang diperoleh dan analisa 
data serta pengujian hipotesis maka dapat disimpulkan sebagai berikut : Nilai rata-rata hasil belajar siswa di kelas XI semester II SMA Negeri 1 Sunggal T.P 2015/2016 yang diajar dengan model Problem Based Learning berbantu Peta Pikiran (Mind Map) pada materi Fluida Dinamis dinyatakan tuntas KKM dimana KKM yang harus dilewati adalah nilai 75 sedangkan pembelajaran Konvensional pada materi Fluida Dinamis dinyatakan tidak tuntas KKM dengan nilai sebesar 66,13. Berarti Ada pengaruh yang signifikan dengan Model Problem Based Learning berbantu Peta Pikiran (Mind Map) terhadap hasil belajar siswa di kelas XI Semester II SMA Negeri 1 Sunggal T.P. 2015/2016.

\section{DAFTAR PUSTAKA}

Imamuddin, M. C. dan U.tomo, N. H., (2012), Efektifitas Metode Mind Mapping Untuk Meningkatkan Prestasi Belajar Fisika Pada Siswa Kelas VIII, Laporan Hasil Penelitian, Universitas Ahmad Dahlan.

Maisyarah, (2013), Efektifitas

Metode Pembelajaran Mind Mapping Terhadap Hasil

Belajar Siswa Pada Mata

Pelajaran Ekonomi SMA, Laporan Hasil Penelitian, FKIP Universitas

Tanjungpura
Rhamadani, W. T., (2015), Pengaruh Metode Pembelajaran Discovery Learning terhadap hasil Belajar Siswa T.P2014/2015, Skripsi, FMIPA, Unimed, Medan

Sani, R. A., (2014), Pembelajaran Saintifik untuk Implementasi Kurikulum 2013. Bumi Aksara, Jakarta.

Svantesson, I., (2004), Learning Maps and Memory Skills, PT Gramedia Pustaka Utama: Jakarta.

Trianto, (2011), Mendesain Model Pembelajaran InovatifProgresif: $\quad$ Konsep, Landasan, dan Implementasinya Pada Kurikulum Tingkat Satuan Pendidikan (KTSP), Kencana, Jakarta. 